i njihove najzanimljivije detalje, kao i kule i čardake sarajevskih porodica od kojih mnogi nisu sačuvani. U ovom poglavlju koje je, uzgred rečeno, i najveće u cijeloj knjizi, autor nabraja čuvene stare ljetnikovce koji su se nalazili na rubnim dijelovima grada, a danas je to dio samog Sarajeva.

Publikovanjem ovog djela, naučna i šira javnost obogaćena je važnim saznanjima koja se odnose na arhitektonsko naslijeđe Bosne i Hercegovine, a koja su dobrobit svim istraživačima opće i kulturne historije, historije umjetnosti, arhitekture, kao i kulture stanovanja.

LAMIJA HATIBOVIĆ

DOI: $10.46352 / 23036974.2021 .272$

\section{Amir Duranović (ur.), Nacije i migra- cije: Studije iz bosanskohercegovačke historiografije. Sarajevo: UMHIS, Sarajevo, 2019, 201 str.}

Čovjek ima potrebu da putuje, istražuje i otkriva nepoznato. $S$ tim karakteristikama moderan čovjek se ne razlikuje u odnosu na ponašanje prvih ljudi na Zemlji. Jedna od teza koju naučnici današnjice zastupaju jeste da je homo sapiens emigrirao sa prostora današnje Afrike. Migracija je, također, čest motiv u Svetim knjigama abrahamističkih religija. Kroz historiju su ostale poznate kolektivne migracije, tj. migracije jednog čitavog naroda od jednog mjesta do drugog. Motivi migracija mogu biti ekonomske, političke, klimatske ili neke druge prirode, što ne umanjuje činjenicu da je migracija prirodan fenomen od postanka ljudskog roda pa sve do danas, koji treba da podstiče istraživače na sagledavanje posljedica izazvanih seobama. Zbornik radova koji propituje uzroke i posljedice migracija kroz perspektivu bosanskohercego- vačkih iskustava nosi naziv Nacije i migracije: Studije iz bosanskohercegovačke prošlosti, čiji je urednik prof. dr. Amir Duranović. Zbornik čine četiri autorska teksta, a koji se mogu podijeliti u dvije grupe. Prvu čine radovi prof. dr. Amile Kasumović i dr. sc. Enesa S. Omerovića koji govore o migracijama na području današnje Bosne i Hercegovine prilikom dva velika događaja. Riječ je o doseljavanju stranaca na navedeno područje nakon što je Austro-Ugarska Monarhija dobila područje Bosne i Hercegovine na upravu, odnosno njihova emigracija nakon Prvog svjetskog rata, tj. u trenutku kada se Monarhija povlači sa ovih područja. U drugi blok radova spadaju članci autora dr. sc. Vere Katz i prof. dr. Husnije Kamberovića. Urednik Amir Duranović ovu grupu radova klasificira kao "propitivanje migracija ideja”, jer autori na odabranim političkim događajima raspravljaju o načinu na koji su određene ideje dolazile u Bosnu i Hercegovinu iz susjednih republika, te se predstavljaju način na koji se rukovodstvo SR BiH nastojalo izboriti protiv takvog uticaja. Zbornik radova predstavlja rezultat rada na projektu "Historiografija i nacionalizam” koje je realiziralo Udruženje za modernu historiju uz kontinuiranu podršku Fondacije Heinrich Böll - Ured u Sarajevu za Bosnu i Hercegovinu, Albaniju i Sjevernu Makedoniju.

Prvi članak nosi naziv Dobro došli u koloniju Eldorado ili nešto treće! Useljavanje u Bosnu i Hercegovinu u prvim godinama nakon okupacije 1878, (str. 25-68) autorice Amile Kasumović. Prvi problem sa kojim se Austro-Ugarska Monarhija susrela, nakon što je na upravu dobila područje Bosne i Hecegovine, jeste pitanje uspostave vlasti. Političkim aktivnostima dogovoreno je da se Zajedničkom ministarstvu finansija u Beču povjeri uprava, čija je produžena ruka vlasti 
bila Zemaljska vlada sa sjedištem u Sarajevu. Autorica u svom radu nastoji obrazložiti motive za migraciju na ovo područje, način na koji je ostvareno političko naseljavanje, te reakcije domaćeg stanovništva. Postavlja se pitanje da li je Zemaljska vlada u početku zaustavljala ili podržavala useljavanje u Bosnu i Hercegovinu, te koje kategorije useljenika su bile favorizirane? Kasumović prenosi, na osnovu dostupne arhivske građe, da su se nakon okupacije podijelile 194 putne isprave, a da je 30 molbi bilo na čekanju. S druge strane, ulazak stranaca se kontrolirao i nije postojalo plansko naseljavanje. Autorica navodi kako su se u štampi prenosile vijesti o kolonizaciji i migraciji u Bosnu, jer su mnogi vidjeli mogućnost zarade. Ipak, bilo je i onih koji su zbog geopolitičke situacije bili nešto oprezniji, jer je sultan još uvijek imao suverenitet nad ovim područjem. Kolonizacija, koja je provedena u vrijeme Austro-Ugarske Monarhije, podrazumijevala je proces naseljavanja većih grupa zemljoradnika na privatnu ili državnu zemlju. U tom pogledu postojao je problem zbog nepostojanja katastra tj. popisa državne zemlje. Masovna kolonizacija na državnu zemlju odvijala se u periodu između 1890. i 1905. godine. Kasumović smatra da je dolazak činovnika u državu, za domaće stanovništvo, bio mnogo veći problem od dolaska privrednika, jer su ovi prvi bili u direktnom kontaktu sa narodom, čime su mijenjali, kako autorica kaže, društveni kolorit. Pored privrednika i činovnika, migraciju su vršili trgovci i avanturisti. Ono što je trgovce privlačilo da dođu u Bosnu i Hercegovinu jeste veliki broj oficira i vojnika, što je značilo da imaju kome prodati robu, a to je podrazumijevalo i veću mogućnost zarade. Tu vrstu privilegije osjetili su i domaći trgovci, koji su se nastojali uklopiti u nove vidove trgovanja, prepoznavši značaj potražnje industrijske robe. Useljavanje novog stanovništva doprinijelo je razvoju novih trendova u trgovinskoj razmjeni dobara.

Za razliku od prethodnog članka, koji je govorio o doseljavanju stranog stanovništva na prostore Bosne i Hercegovine početkom okupacije, rad autora Enesa S. Omerovića govori o iseljavanju tog istog stanovništva ili njihovih potomaka nakon kraja Prvog svjetskog rata, a nosi naziv "Odlazak kuferaša". Iseljavanje stranaca iz Bosne i Hercegovine neposredno nakon Prvog svjetskog rata (str. 69-121). Autor u uvodnom dijelu konstatuje da je po popisu stanovništva iz 1910 . godine bilo oko 120.000 registriranih doseljenika. Pojam "kuferaš" predstavlja pogrdan naziv za novopridošlo stanovništvo. Zanimljivo je da se kofer, odnosno ručni prtljag, utkao kao negativan pojam u kolektivnu svijest starosjedilaca, a posredstvom stranaca, jer simbolizira putnika, odnosno dolazak novog stanovništva na ovo područje. $\mathrm{Na}$ osnovu samog izraza "kuferaš" može se osjetiti netrpeljiv odnos domaćeg stanovništva spram doseljenika. Nakon Prvog svjetskog rata austro-ugarska vojska se povlačila iz Bosne i Hercegovine, a to je izazvalo haotično stanje na terenu. Veliki broj pljački i ubistava obnovio je strah među lokalnim stanovništvom, što je dodatno narušilo, crnu sliku o doseljenicima. Autor je izvršio podjelu na tri načina iseljavanja. Prvo je samoinicijativno i pojedinačno iseljavanje, koje nije bilo organizirano, dešavalo se tokom oktobra i novembra 1918. godine, a činili su ga dužnosnici Zemaljske vlade i niži činovnici. Učesnici prvog vala iseljavanja napuštaju domove i prestaju se pojavljivati na poslu. Omerović smatra da je, zapravo, riječ o bježanju, jer se oni ne pojavljuju u izvorima zbog potražnje ličnih dokumenata ili nekih drugih sličnih zahtjeva. Drugi način iseljavanja bio je 
organiziran iseljeničkim željezničkim transportima. Karakteristika ovog načina odlaska iz zemlje jeste što su ga uglavnom činili vladini činovnici, koji su tražili način da prije odlaska riješe egzistencionalno pitanje. Autor je uvidio da izdate dozvole i spisak ličnih stvari predstavljaju vrlo interesantne dokumente na kojima su nastali stereotipi o kuferašima, jer su "u Bosnu došli praznih ruku, a odlaze kao bogati”. Pored dva navedena načina iseljavanja, postojao je i veliki broj stranaca koji je protjeran. Oni nepoželjni bili su Nijemci, Austrijanci, Mađari, Bugari, državljani neprijateljskog Osmanskog Carstva i slično, dok Česi i Poljaci nisu predstavljali problem. Kasnije su državne vlasti shvatile da protjerivanje ne mora nužno biti produktivno i da može uticati na diplomatske odnose. Omerović je, također, u okviru svog istraživanja komparirao popis stanovništva iz 1910. i 1921. godine i zaključio postojanje demografskih gubitaka, što je uzrokovalo druge probleme poput kadrovskih rješenja na raznim važnim državnim funkcijama, te osipanje školovanog kadra.

Treći članak unutar zbornika, a prvi koji govori o "migraciji ideja", djelo je autorice Vere Katz pod naslovom Odjeci u Bosni i Hercegovini povodom objavljivanja "Deklaracije o nazivu i položaju hrvatskog književnog jezika" i "Predloga pitanja za razmišljanje" (str. 123-173). Višenacionalna struktura stanovnišstva, isprepletena sa problemom neriješenog nacionalnog pitanja, zadavala je glavobolje partijskom rukovodstvu uvijek kada bi se problemi susjednih Republika nastojali prenijeti u Bosnu i Hercegovinu. Načelo "bratstva i jedinstva" bilo je ugroženo onda kada su se javljale ideje koje nisu u skladu sa politikom koju je propagirao vrh Partije. Jedna od takvih je i "Deklaracija o nazivu i položaju hrvatskog književnog jezika” objav- ljena u martu 1967. godine, kojom se tražilo da se hrvatskom književnom jeziku osigura ravnopravnost i jednakost. Autorica je u svom radu komparirala predstavljanje ovog problema u listu Oslobođenje sa informacijama iz zvaničnih dokumenata Centralnog komiteta Bosne i Hercegovine (CKBiH). Katz ukazuje da je od objavljivanja deklaracije do zvaničnog istupanja bosanskohercegovačkih političara prošlo 12 dana, koji su smatrali da je Deklaracija nastavak hegemonističkih aspiracija prema Bosni i Hercegovini. Autorica je uporednom analizom tekstova koji su izlazili u Bosni i Hercegovini i listova koje su izlazili u susjednoj Srbiji i Hrvatskoj utvrdila kako se u ovim prvim mnogo češće upotrebljava slogan "bratstvo i jedinstvo", što je u susjedstvu zamijenjeno terminima poput "nacionalna ravnopravnost”, "dobri međuljudski odnosi”, "bratski narodi” i slično. Također, Katz govori i o kontekstu vremena u kojem se sve odigravalo. Novine su bile pune naslova i podsjećanja na slavnu historijsku prošlost, partizanski pokret, ali i uspjehe nakon Drugog svjetskog rata. To su priče na kojima je insistirala generacija koja je iznijela pobjedu nad fašistima. $S$ druge strane, ti podaci bili su namijenjeni mladima koji za to nisu bili zainteresirani jer, kako autorica navodi, nudilo im se programski nešto u što ni komunisti nisu bili ubijeđeni. Umjesto toga, omladina je sve više gledala ka Zapadu. Iz Partijskih dokumenata može se uvidjeti da su postojala različita reagiranja na pojavu Deklaracije, što je ovisilo o nacionalnoj sredini, ali i da su viši i niži nivoi unutar Partije različito posmatrali cjelokupnu situaciju. Katz zaključuje da su općinski komiteti kontrolirali cijele zajednice, čime nisu dozvoljavali da se njihova pozicija ugrozi, a da je postojao veliki raskorak između onoga što se dešavalo u $\mathrm{CKBiH}$ i onoga što se prezentiralo u javnosti. 
Husnija Kamberović autor je posljednjeg rada u Zborniku pod nazivom Studenti iz Hercegovine na sveucilištu u Zagrebu u doba Hrvatskog proljeća (str. 175-195). Autor navodi da je u vrijeme Hrvatskog proljeća bilo mnogo više hercegovačkih studenata na Univerzitetu u Zagrebu, nego u svim ostalim federativnim centrima. Studenti su bili organizirani u studentska društva u vidu zavičajnih studentskih klubova, a aktivnost se posebno povećala u periodu 1971. godine. Kamberović smatra da je studentsko udruženje Zavičajni klub studenata Hercegovine, uz Maticu Hrvatsku, bio jedan od najjačih veza Hrvatskog proljeća sa Hrvatima iz Bosne i Hercegovine. Oni su širili svoj uticaj i ideje, koje su se odnosile na nacionalno pitanje i položaj Hrvata, jezičko pitanje, etiketiranje Hercegovaca, iseljavanje Hrvata i druga slična pitanja. Njihov lobi i uticaj je bio mnogo snažan, ali se u zvaničnim izvještajima uticaj omladine nastojao minimalizirati. Kamberović je u radu predstavio primjer osnivanja Općinske sekcije kluba iz Duvna 1971. godine, čije je osnivanje i djelovanje bilo ocijenjeno kao negativno. Naime, na području Hercegovine u ovom periodu imamo dvije frakcije. Prva je djelovala pod uticajem ideja Hrvatskog proljeća. Na ovom mjestu moramo ukazati da je u ovakvim i sličnim hercegovačkim udruženjima bilo studenata iz raznih krajeva tog područja, što je zapravo predstavljalo problem za CKBiH. Drugu frakciju su predstavljali središnji studentski i politički krugovi u Bosni i Hercegovini. Kada ovome svemu dodamo da je područje Zapadne Hercegovine imalo stigmu "ustaškog područja", jasno je sa kakvim se problemom republički komitet suočavao. Zbog navedenog partijski rukovodioci iz lokalnih sredina su podsticali Savez studenata Bosne i Hercegovine da se suprotstave širenju nepopularnih ideja
Hrvatskog proljeća. Savez studenata oglasio je da niko ne može djelovati bez njihove saglasnosti među mladima na teritoriji Bosne i Hercegovine smatravši Savez studenata Hrvatske odgovornim za okretanje hercegovačke omladine. Kamberović zaključuje da studentski pokret nije imao dovoljno snage da djeluje samostalno bez političkog pokroviteljstva Partije.

Zbornik radova Nacije i migracije: Studije iz bosanskohercegovačke prošlosti nastajao je u jeku migrantske krize. Dok su jedni dizali zidove i bodljikave žice, kako migranti sa područja Afrike i Bliskog Istoka ne bi ušli u njihovu državu, ruta kretanja ovih ljudi se usmjerila ka području Bosne i Hercegovine. Način prihvatanja "gosta” od strane domaćeg stanovništva bio je šarolik. Jedni su pružali ruku pomoći argumentirajući kako ih treba razumjeti i prihvatiti "jer smo i mi bili u istoj situaciji u periodu 1992-1995”, dok su drugi negodovali u strahu za vlastite živote i imovinu. Ovo nam je važno imati u vidu i zbog historijskog konteksta, jer je zanimljivo pratiti proces povlačenja Osmanskog Carstva sa ovog područja i reakcije domicilnog stanovništva nakon što su shvatili da dijele životni prostor sa strancima, te komparirati navedeno sa onim što imamo danas u novim historijskim okolnostima. Članak Amile Kasumović govori o doseljavanju stranaca na područje Bosne i Hercegovine, a Enes Omerović govori o njihovom odlasku, što omogućava čitaocima da stvaraju širu sliku o migracijama i demografskim promjenama, na ovom području, te promjenama u strukturi stanovništva koje su se desile za manje od pedeset godina. Iz navedena dva rada možemo uvidjeti koliko promjena političkog sistema može uticati na ponašanje pojedinca ili jedne grupe ljudi, što također možemo vidjeti i iz radova Vere Katz i Husnije Kamberovića. 
Treći i četvrti rad, za razliku od uvodnih, govore o migraciji ideja, ali u sasvim drugačijim historijskim okolnostima i političkim sistemima. Sigurno je da će ovaj Zbornik, u čemu se ogleda i važnost datih tema, dati nešto drugačije perspektive o razumijevanju današnjice, jer se niti jedna seoba stanovništva nije desila preko noći. Seobe naroda o kojima učimo u udžbenicima su proces koji traje određeno vrijeme. Posljednjih nekoliko godina u Bosni i Hercegovini se odvijaju dva paralelna procesa. Jedan gdje su migranti sa Bliskog Istoka i iz Afrike "zapeli" u Bosni i Hercegovini, a zbog čega je određeni broj odlučio ostati u državi i tu pronaći svoju sreću, dok s druge strane pratimo trend bosanskohercegovačkog stanovništva koje napušta matičnu domovinu, te se upućuje ka razvijenijim zemljama Zapada. Sigurno da će i ova tema za određeno vrijeme, nakon što konačno vidimo rezultate navedenog procesa, biti zanimljiva istraživačima.

\section{ALEN BORIĆ}

DOI: $10.46352 / 23036974.2021 .276$

\section{Amir Duranović, Povijest, historija, bistoriografija. Sarajevo: Udruženje za modernu historiju, 2020, 212 str.}

Knjiga Povijest, historija, historiografija objavljen je 2020. godine u izdanju Udruženja za modernu historiju, uz podršku Fondacije Heinrich Böll. Sadržaj knjige podijeljen je na tri cjeline gdje je moguće pronaći tekstove profesora Univerziteta u Sarajevu, Amira Duranovića, koji su nastajali u proteklih deset godina njegove karijere. Tekstove sabrane u ovoj knjizi povezuje jedna zajednička nit, tiču se mjesta i uloge historičara u društvu.

Prvo poglavlje, naslovljeno Povijest čine autorovi intervjui dati različitim medijskim kućama u Bosni i Hercegovini, povodom obljetnica, objavljivanja knjiga ili drugim povodima. U ovom dijelu moguće je čitati razgovore $s$ novinarima o motivima smjene Aleksandra Rankovića, o aferi "prisluškivanje”, UDBI i slično. Cjelina Povijest sadrži i razgovor s profesorom Husnijom Kamberovićem, održan u septembru 2020. godine u okviru History Fest-a. Tu čitamo značajne podatke o projektu Historiografija $i$ nacionalizam Udruženja za modernu historiju koji se može pohvaliti da je tokom tri godine trajanja navedenog projekta ostvario značajne rezultate: održane su konferencije, radionice, objavljeni zbornici i, što je možda i najznačajnije, okupljeni su mladi doktoranti Univerziteta u Sarajevu ili drugih univerziteta s kojima je ostvarena saradnja i razmjena iskustava.

Drugu cjelinu u ovom zborniku naslova Historija čine tri teksta s okruglih stolova i konferencija organizovanih od strane Fondacije Heinrich Böll. To su tekstovi Die Wahrnehmung des Ersten Weltkriegs in Bosnien und Herzegowina (91-100), Razmišljanja o 1917. godini u Bosni i Hercegovini danas (101-110), te Pogled na antifasizam danas, 75 godina poslije ZAVNOBiH-a (111-122). Posljednji dio ovog zbornika čini osam tekstova - prikazi, recenzije i osvrti koje je autor objavljivao u proteklih deset godina ponukan projektima čiji je dio bio. Ovu je cjelinu autor naslovio Historiografija i u njoj se najprije nalaze prikazi knjiga nastali u periodu 2009-2016. godine. Tu je moguće čitati autorov osvrt na jednu političku biografiju, zatim prikaz za koji je autor nagraden Novogodišnjom nagradom Biblioteke XX vek. Tu je i prikaz djela Adnana Jabića, Islamska zajednica u Bosni i Hercegovini za vrijeme monarbističke Jugoslavije (1918-1941),koji je Duranović napisao i objavio prije deset godina, te prikazi drugih publikacija iz navedenog perioda. Na kraju 